\title{
Rastros de histórias ou as Mortes de José
}

\author{
Adelaide Gonçalves ${ }^{1}$
}

ALMEIDA, Nilton. Fortaleza Rebelde: cartografia das lutas dos trabalhadores ferroviários em Fortaleza. Fortaleza: Ediçôes SECULT, 2012

Um livro pode ser lido de muitos modos. Aqui, a sensibilidade do leitor vai destrinçando os fios da trama a partir dos fragmentos de uma memória da dor nos depoimentos de familiares, filhos, amigos e viúvas dos trabalhadores ferroviários. Observe-se a dimensão dos textos testemunhais em seu propósito político e educativo: transmitir experiências coletivas da luta política, assim como os horrores da repressão, em um intento de indicar caminhos e marcar com força o 'Nunca Mais', como na arguta abordagem de Elizabeth Jelin. Veja-se, inclusive, como este estudo pode suscitar seguidas reflexôes sobre certas grandes ausências nas narrativas, como é o caso das mulheres. Num mundo do trabalho predominantemente masculino, elas terão assumido apenas os papéis prescritos: professoras, escriturárias, assistentes sociais? Na fotografia do III Congresso Nacional Sindical, em 1960, no Teatro João Caetano, no Rio de Janeiro, numa tomada do palco e da lateral do auditório, muitos engravatados e de paletó, outros em mangas de camisa e nenhuma mulher.

Neste livro, uma diversa cartografia da cidade de Fortaleza. O autor esquadrinha a cidade em direção às estaçôes do trem, aos bairros cortados pelos caminhos de ferro, aos espaços de confraternização e organizaçáo da classe,

1 Professora do Departamento de História da Universidade Federal do Ceará 
ao lugar de morada nas vilas operárias. Os mapas da luta social nos levam a conhecer também os lugares do protesto no meio da rua, dos meetings e das passeatas, dos comícios-monstro, no dizer do jargão policial. Nessa singular geografia, as Praças formam um lugar especial no coração da cidade, tomadas pelos estandartes, bandeiras e quepes jogados ao alto, em sinal de regozijo com as miúdas vitórias e grandes esperanças. As lembranças vivas da Praça do Ferreira, suas árvores, o convívio, a boa conversa no banco da praça, o banco dos comunistas se transmutando em "jornalismo falado", no dizer de Alberto Galeno. Pois em 1968, ano ruim, o engenheiro, que fazia às vezes de prefeito, manda reformar a praça. Assim se foi o banco e um tempo... Parecia uma vingança, pois o homem é o mesmo engenheiro das contendas com os ferroviários da RVC.

"Na cidade, vive-se por ruas", e "a porta principal da casa abre para a rua”, para a vida no bairro, com as solidariedades de vizinhança e, quando se pode, morando toda a vida na mesma casa. Isso os patróes compreenderam bem e logo: como se vê nas vilas operárias. Casas amealhadas segundo os critérios estipulados pelos patróes: sorteio para trabalhadores de muitos filhos, que achavam um jeito de acomodar até catorze, fazendo um puxadinho no quintal. A propaganda (enganosa) nos jornais dos anos 1930 anuncia à gente trabalhadora o milagre de se tornar proprietário de um lote de vinte e cinco palmos. Em suas casas com portas de ficha e piso de cimento, ou em “casinhas de duas portas e uma só água”, os ferroviários e suas famílias vão se espalhando na cidade - Jacarecanga, Farias Brito, Rodolfo Teófilo, Pici, Pan Americano,Bela Vista, Parangaba - e nos bairros proletários do Monte Castelo, Pirambu, Carlito Pamplona.

Mas as formas de habitar e os bairros não são os mesmos para toda a gente. Ali, na esquina da Rua Castro e Silva com a Vinte e Quatro de Maio, oito casas, em estilo bangalô, atestavam a hierarquia do trabalho na estrada de ferro: o jeito melhor de morar era reservado ao senhor engenheiro. Hoje, não restam bangalôs para contar essa história: um prefeito a mais da escola-do-bota-abaixo derrubou os bangalôs para alargar a rua...

$\mathrm{Na}$ cidade dos ferroviários, este livro nos fala de seus lugares do divertimento, de seus clubes, dos locais da boa prosa, do trago de pinga e do convívio entre iguais. Nessa história do povo, o futebol tem lugar certo. Do futebol como uma brincadeira da camaradagem, quando os trabalhadores querem ser donos do tempo livre. Logo aparece o time inventado pelo 
engenheiro Couto Fernandes, em 1919, o Olimpico Football Clube, pois os engenheiros estão sempre à espreita querendo em tudo mandar, até chegar ao Ferroviário, time oficial, da empresa. Mas a história prega peças aos desavisados; o time da empresa vira o Ferrim dos comunistas e anarquistas, da resistência coral proclamada: "nem guerra entre torcidas, nem paz entre classes"; "nada diminui nossa paixão incendiária, ferroviário, orgulho da classe operária”. O Ferrão com seu grito e seu hino.

A alegria das lembranças é fato notável neste livro. Quando a memória é acionada para lembrar as invençóes da política da classe, é com alegria que se lembra a força da novidade do Pacto Sindical no final dos anos 1950. "Era um movimento bonito e animado", no dizer de Zé Leandro. A luta era bonita e alegre! Era o tempo dos meetings, dos comícios-monstro entoando os hinos do Jataí e dando vivas ao Partidão. Como atestam os instantâneos, registrando na fotografia uma celebração coletiva da vitória da classe, até ontem em pé de guerra, no dizer da manchete em vermelho do jornal Unitário, na greve do "fora Humberto Moura", em 1961: piquetes, dormentes dos trilhos e blocos de cimento virando barricadas, carros de rodas para cima, barraca da resistência; na capital e no interior, como se vê nas fotografias em frente à oficina do Urubu, em Sobral ou no Ipu. Fotografias de gente no plural, encenando os coletivos e a coreografia da luta social.

Aliás, o sentido da luta como festa redentora é recuperado em outras passagens deste estudo. É de se ver a camaradagem, a conversa entre iguais e o dizer-de-tudo dos ferroviários ali no bar pertinho do sindicato, espécie de território livre, onde se encontravam e de tudo falavam. Nesse convívio, até os apelidos - o Cajarana, o Catita, o Caboclinho, o Sol Quente, o Sereno, o Macarrão - são os sinais da camaradagem atualizando as conversas. Dali, saíam confiantes para inventar as coreografias do protesto narradas neste livro. Passeatas contra a carestia, de solidariedade aos bancários e estudantes. É de se imaginar a beleza dos braços dados acompanhando o vozeirão de José Jatahy e o som da radiadora tocando um hino de classe dos ferroviários. A letra é luminosa, alvissareira, confiante e esperançosa. Num lampejo de memória, o Sereno diz que aquilo era uma época diferente... Era a maior festa... Bastava um grito: pára o trem! E pronto, a greve estava na praça, na rua. Aliás, a greve é rememorada como uma grande festa: da liberdade, do não ao patrão, de quando o trabalhador se manifesta, dá vazão a todo seu sentimento, como na recordação de Batistinha. Afinal, o aprendizado das 
greves desde os finais do oitocentos aumenta nos começos do novo século. Ferroviários, marítimos, portuários e o "pessoal agrícola” do Chico Julião mobilizavam-se em busca de direitos.

Em busca de direitos denegados. É outro mote deste livro. As tricas e futricas da política local emergem neste estudo por dentro das situaçôes de impasse entre a organização dos trabalhadores ferroviários e a direção da RVC. Em alguns casos, a narrativa encaminha o leitor para uma história à maneira de "queda de braço", como se vê no malogrado episódio da demissão do engenheiro José Walter. Era chegado o golpe civil-militar. Tempos difíceis e cinzentos. Acabou a festa. Intervenção, demissão, perseguição, prisão. $\mathrm{O}$ vocabulário é outro. A desmesura do arbítrio não tem limite: os ferroviários mais à frente das lutas sindicais são proibidos até de passar por perto da empresa. E se pegos andando na estação central, cadeia neles! É a ordem do doutor engenheiro. A vida mudou demais para esses trabalhadores e suas famílias. Casas invadidas, perseguições, prisões, demissôes, o cárcere, a vida virada de ponta-cabeça. O controle, a vigilância, "os alcaguetes estavam por todo lado: disfarçados e traiçoeiros".

Por dentro desta narrativa emergem outras histórias dos militantes comunistas e de suas vivências no Partidão. Uma visada retrospectiva parece tudo compreender. Mas, bem vistas as coisas, náo é assim. Para alguns militantes, a memória traz de volta uma história atribulada, lembrada com algum travo, de divergências, sectarismos, uma linha justa tirada lá em cima, no comitê central. Para outros, é uma história de autoesclarecimento, de aprender a ler, de estudar nas horas vagas para mostrar o valor da classe, de se tornar "jornalista da classe”. Aliás, este livro traz boas passagens para a história do jornalismo no Ceará. E do jornalismo da militância comunista, como aquele praticado por Jonas Daniel em franco combate à ditadura, fazendo funcionar em Croatá uma tipografia, melhor dizer, um mimeografo elétrico adaptado à função manual, donde saía o Voz Operária, a Estudos e Mundo em Revista e, de quebra, uns quantos panfletos, pois a luta também se travava por impresso. Sobre o fato, o jornal O POVO estampa, em abril de 1973: Imprensa comunista desmantelada no Ceará. A notícia, ao modo do jargáo policial, indica os "elementos" presos e se fica sabendo que desmantelar é literal, levar tudo: máquina impressora, grampeador industrial, aparelhagem de fundição de chumbo, guilhotina, clichês, latas de tinta - e prender os 'subversivos'. Rememorando aquele tempo, Dona Nazareth, viúva de Jonas 
Daniel, é daquelas que "viveu para contar", e sua memória tem saudades e é alegre: terá valido a (a)ventura de ser comunista. Como é o caso também de Caboclinho Farias. Perguntado como se tornara comunista, responde depressa: por meio da leitura! A comprovar o dito, o processo na polícia traz o rol de sua literatura de formação: desde o manifesto comunista, compêndios de história, manuais de difusão do marxismo-leninismo, boletins, até recuerdos de suas viagens militantes. Outras boas histórias de dedicados militantes comunistas: Mascarenhas, Zé Maria, Graciano, José Elias, Anário, Zé Duarte, entre tantos, em sua peleja até na cadeia!

Este livro nos dá a pensar também sobre o capítulo da história da destruição dos livros nas ditaduras. Esse episódio terrível deve ser contado. Terá sido uma hora de muita aflição, quando se sabia acuado pela repressão, enterrar ou queimar os livrinhos. Já os meganhas, quando chegam - e a qualquer hora - vão direto aos livros! Livro é prova do crime de pensar. A comprovar essa sanha contra a palavra impressa, estão aí os processos com extenso rol de livros. A ditadura prende os livros, confisca o pensamento, esse um capítulo de grande significado na história social da interdiçáo do livro e da leitura.

Este livro-documento terá cumprido largamente a tarefa abraçada desde o início da intenção de pesquisa. Tentar juntar os pedaços da história do ferroviário José Nobre Parente, 37 anos, preso, mantido incomunicável, assassinado na prisão. José perdeu a vida duas ou mais vezes: assassinado na prisão e apagado dos registros das vítimas da ditadura civil-militar - seu processo na Comissão é parcamente documentado. Perde a vida e a memória é chafurdada. Dele se diz: fraco do juízo, é um suicida. Macabra e porca história tantas vezes falsificada nos prontuários de polícia. José, Manoel, Vladimir terão sido - e continuam sendo - as vítimas da tortura. Esse o nome do bicho, sobre o qual pesam os espessos silêncios convenientes da autoridade policial e o esquecimento deliberado e cúmplice da imprensa local. Amnésia e anistia. Quem matou José? É a pergunta que se faz o jornalista e historiador Nilton Almeida. Pinça da manchete de Última Hora, do jornalismo dissidente, constituindo esses desvãos de memórias persistentemente ocultadas e contrastando versóes impressas dos terríveis atos da ditadura. Neste ponto, no âmbito do direito à memória, é de se proclamar a necessidade urgente de amplo inventário e divulgação de fontes do acervo dos documentos da polícia 
política do Ceará, o acervo do DOPS, sob a guarda do Arquivo Público do Estado do Ceará.

Este livro é trabalho meticuloso de um sincero historiador. Comprometido com a faina do ofício, Nilton Almeida tem no arquivo uma oficina e entende a escrita da história como prática laboriosa de desmontar versôes oficialmente arranjadas sobre episódios e personagens, nomeadamente esses "notáveis" que nomeiam bairros, avenidas, logradouros, retirando de sua ação sobre os tempos e lugares os conteúdos do arbítrio, da repressão, do mando. Também é esforço bastante bem realizado de sair dos trilhos da história institucional da estrada de ferro em busca das outras histórias dos trabalhadores, de suas famílias, de seu jeito de viver e de aprender a soletrar as palavras da luta social. É também um respeitoso exercício de escuta das memórias do silêncio ou dos papéis oficiais, em particular, das mulheres-viúvas, algumas de maridos mortos-vivos. Mulheres que, às vezes, se acostumaram a andar de olhos baixos para não ver o dedo apontando o estigma do marido preso pelo crime de ser comunista.

Recebido em: 16/07/2012

Aprovado em: 02/08/2012 